\title{
ORIGIN OF ADENOCARCINOMA IN BARRETT'S ESOPHAGUS: P53 AND KI67 EXPRESSION AND HISTOPATHOLOGIC BACKGROUND
}

\author{
Sergio Szachnowicz, Ivan Cecconello, Kiyoshi Iriya, Allan Garms Marson, Flávio \\ Roberto Takeda, and Joaquim José Gama-Rodrigues
}

SZACHNOWICZ S et al. Origin of adenocarcinoma in Barrett's esophagus: p53 and Ki67 expression and histopathologic background. CLINICS 60 (2):103-112, 2005.

Barrett's esophagus is the substitution of squamous epithelium of the distal esophagus by columnar epithelium. Intestinal metaplasia in Barrett's esophagus is considered to be the main risk factor for the development of adenocarcinoma. Diffuse adenocarcinoma and Barrett's esophagus without intestinal metaplasia are rare, and reports on the subject are scarce.

PURPOSE AND METHOD: To estimate the prevalence of adenocarcinoma in 297 patients with Barrett's esophagus, during the period of 1990 to 2002, and in 13 patients undergoing surgery, to conduct detailed macroscopic and microscopic analysis, with performance of immunohistochemical tests for p53 and Ki67, correlating the type of tumor with its adjacent epithelium.

RESULTS: In our patients with Barrett's esophagus, there was a prevalence of $5.7 \%$ of adenocarcinoma. The tumors developed only when the Barrett's esophagus segment was long $(>3.0 \mathrm{~cm})$. Tumors were located close to the squamouscolumnar junction. The histological study revealed 2 patients $(15.4 \%)$ with Barrett's esophagus adjacent to a tumor with gastric metaplasia without the presence of intestinal metaplasia. Tumors were classified according to Nakamura's classification (23\% differentiated pattern, and 77\% undifferentiated pattern) and to Lauren's classification (61\% intestinal and 39\% diffuse). The difference is due to the migration of microtubular and foveolar tumors of undifferentiated (gastric) pattern in Nakamuras classification to the Lauren's intestinal type. The immunohistochemical test for Ki67 was strongly positive in all the patients, thus evidencing intense cell proliferation in both the columnar epithelium and tumor. Expression of p53 was negative in $67 \%$ of the adjacent columnar epithelia and $42 \%$ of the tumors, without any correlation between the tissue types.

CONCLUSION: Adenocarcinoma develops from mixed columnar epithelium, either intestinal or gastric, showing both the gastric and the intestinal patterns; thus, tumors can also grow in columnar epithelium without intestinal metaplasia. Barrett's esophagus should be followed up for the possibility of progression to malignancy, especially when the segment is longer than $3 \mathrm{~cm}$.

KEYWORDS: Barrett's Esophagus. Gastroesophageal Reflux. Esophageal Neoplasia. Adenocarcinoma. Immunohistochemistry.

Currently, Barrett's esophagus is defined as the presence of columnar epithelium in the esophagus with intestinal metaplasia ${ }^{2-6}$ Other investigators consider Barrett's esophagus to be just the substitution of the stratified epithelium in the distal esophagus by columnar epithelium,

From the Department of Gastroenterology, Faculty of Medicine, University of São Paulo - São Paulo/SP, Brazil.

E-mail: sergiosz@ig.com.br

Received for publication on July 30, 2004.

Accepted for publication on December 10, 2004. either gastric (junctional) or intestinal., ${ }^{1,-9}$ The columnar epithelium with intestinal metaplasia is more frequently seen than the gastric type. ${ }^{10}$ Macroscopically, Barrett's esophagus is classified as long when it presents a segment of columnar epithelium longer than $3 \mathrm{~cm}$, and short when it is shorter than $3 \mathrm{~cm} .^{10,11,12}$

In some specimens of esophagectomy for adenocarcinoma in Barrett's esophagus (ABE), the adjacent columnar epithelium frequently presents with intestinal metaplasia with a dysplastic alteration. ${ }^{2}$ However, others present with 
a gastric epithelium type adjacent to the tumor. ${ }^{13-15}$ Despite those findings, by the end of 1980s, intestinal metaplasia was specifically defined as a predictive factor for development of $\mathrm{ABE},{ }^{2,6,17-23}$ and the presence of gastric columnar epithelium in the distal esophagus was not associated with adenocarcinoma development. ${ }^{24,25}$ However, some reports mention adenocarcinomas growing in Barrett's esophagus without intestinal metaplasia in columnar epithelium. ${ }^{16,26,27}$

Another risk factor for adenocarcinoma development is the extent of the columnar epithelium in the esophagus, ${ }^{6,18,28}$ being more frequent in Barrett's esophagus with segments longer than $4 \mathrm{~cm}^{7,25,26,29}$

The most used classification of ABE is the Lauren's classification of gastric tumors, ${ }^{30}$ which divides neoplasia into diffuse and intestinal according to the microscopic morphology shown by the tumors. There are other detailed classifications, such as Nakamura's, ${ }^{31}$ which classifies gastric adenocarcinomas into differentiated and undifferentiated types. The first originates from gastric intestinal metaplasia and the latter from the gastric mucosa itself.

The progression of columnar epithelium to dysplastic and to adenocarcinoma has been studied in the last decade with genetic and immunohistochemical (IHC) markers, ${ }^{33-35}$ aiming to identify some marker that could predict evolution of Barrett's esophagus to adenocarcinoma. ${ }^{28}$ Studies of p53 in Barrett's esophagus show high positive expression rates of IHC markers in patients with high degrees of dysplasia and adenocarcinoma, and rare expression in normal mucosae or in esophagitis. ${ }^{36,37,38}$ Cell proliferation has been reported to be one of the first steps in the development of $\mathrm{ABE}$, and it can be induced by chronic cell damage caused by gastroesophageal reflux. The IHC-identified expression of Ki67 in Barrett's esophagus has been studied to evaluate the increased cell proliferation, ${ }^{40}$ which was found to be enhanced only in ABE and in high-degree dysplasia, less expressed in low-degree dysplasia and Barrett's esophagus without dysplasia. ${ }^{41}$ Since this is a simple exam that can be performed in most large centers, the study of the association of Ki67 and p53 has been employed with the purpose of trying to define intermediate biological markers in $\mathrm{ABE}$ development through dysplasia, as well as to differentiate dysplasia from adenocarcinoma. The expression of Ki67 and p53 together has already been studied. ${ }^{41-34}$ The presence of those markers in Barrett's esophagus, both in the dysplastic epithelium and in ABE, has not yet been standardized, and there is great variation in the results. The study of IHC reactions to correlate adenocarcinoma with adjacent columnar epithelium has not yet been accomplished.

The objective of this study was to estimate the prevalence of adenocarcinoma in patients with Barrett's esophagus, to evaluate the extension of the columnar epi- thelium and the extension and location of the adenocarcinomas; to identify the different histological types of tumor growth in Barrett's esophagus and to correlate them to the histological type of the adjacent columnar epithelium, and to analyze, using IHC tests, expression of p53 and Ki67 in both the tumor and the adjacent columnar epithelium.

\section{MATERIALS AND METHODS}

From January 1990 to June 2002, the medical records of a total of 297 patients with Barrett's esophagus, hospitalized at the Department of Gastroenterology of the Faculty of Medicine, University of São Paulo, were retrospectively analyzed. Adenocarcinoma was evidenced in 17 patients, with a prevalence of $5.7 \%$ of ABE.

Gastric fundus and cardia tumors invading the esophagus were excluded. From the 17 patients, 3 presented with advanced neoplasia and underwent palliative treatment without tumor resection. One patient underwent argon plasmatic ablation of the columnar epithelium, including the tumor, which was not identified in the histopathological study of the resected esophagus. The remaining 13 patients underwent esophageal resection and were the main focus of this study. This sample comprised 11 men $(84.6 \%)$ and 2 women (15.4\%), a 5.5:1 ratio. Twelve (92.3\%) were white, with ages ranging from 40 to 75 years (mean $60.75 \pm \mathrm{SD}=$ 9.88).

\section{Histopathological study}

The resected esophagus was opened longitudinally, photographed, stretched onto a plain plastic or cardboard surface, and kept in a $10 \%$ formol solution for 1 to 4 days. After this period, the tissue was photographed again and the columnar epithelium and tumor lengths were measured. The distances from the distal limit of the tumor to the gastroesophageal junction (Dist. Tu-GEJ) and from the proximal limit of the tumor to the columnar-squamous transition (Dist. Tu-Tepit) were assessed.

Paraffin blocks containing fragments of tumor and adjacent epithelia were sectioned, stained with hematoxylineosin (H\&E), and prepared for histological analysis by light microscopy.

The histological type of the columnar epithelium adjacent to the tumor was classified into (i) fundic, consisting of parietal and main cells; (ii) gastric (pyloric or cardiac), consisting of mucous glands without parietal cells; (iii) intestinal, with a villiform surface with crypts and goblet cells (specialized columnar epithelium); and (iv) mixed, which could be associated with more than one type of epithelium. Tumors were classified according to Laurén ${ }^{30}$ and 
Nakamura's ${ }^{31}$ classification, as modified by Iryia et al. (1999) for gastric adenocarcinomas, generally used by the Brazilian Pathology Association (BPA) ${ }^{32}$ (Table 1).

\section{Immunohistochemical study}

The expression of p53 and Ki67 antigens was revealed by immunohistochemical (IHC) tests of adenocarcinomas and adjacent columnar epithelia. Biological material from the columnar epithelium and adjacent adenocarcinoma of 9 and 12 patients, respectively, was recovered in paraffin for the IHC tests that were performed using Banks' technique $^{42}$. After this reaction, the catalyzed antibody generated a brown color expressed in the cellular nuclei when the antigen that was the subject of analysis was present. The expression of the IHC reaction was analyzed in the most red-stained areas, when present, and quantitatively classified as negative (-) (no nuclei expression); minimal (+) (nuclei expression up to 5 cells per gland, or discretely $(<33 \%$ of nuclei expression of the total area) in undifferentiated neoplasias); moderate (++) (nuclei expression from 5 to 10 cells per gland, or (between $33 \%$ and $66 \%$ of nuclei expression of total area) in undifferentiated neoplasias); and maximal (+++) (nuclei expression above 10 cells per gland, or intensely ( $>66 \%$ of nuclei expression of total area) in undifferentiated neoplasias).

\section{Histopathological Results}

Measurements obtained from each resected esophagus are shown in Table 2. Columnar epithelium length ranged from 3.5 to $16.0 \mathrm{~cm}$ (mean $7.71 \mathrm{~cm}, \mathrm{SD}=3.33$ ). Tumor length ranged from 1.5 to $7.4 \mathrm{~cm}$ (mean $4.67 \mathrm{~cm}, \mathrm{SD}=2.28$ ). All the adenocarcinomas developed in cases of Barrett's esophagus segments longer than $3.0 \mathrm{~cm}$, and were more frequent in the longest ones $(>6.0 \mathrm{~cm})$. Distances from the distal limit of the tumor to the gastroesophageal junction (Dist. Tu-GEJ) ranged from tumors located in the GEJ (5 patients $-38.5 \%$ ) to tumors located $14 \mathrm{~cm}$ away from the GEJ (mean $2.07 \mathrm{~cm}$ ) (Figure 1). Distances from the proxi-

Table 1 - Comparison between Laurén's and the Brazilian Pathology Association's (BPA) classifications for gastric adenocarcinoma.

\begin{tabular}{llll}
\hline BPAIntestinal Pattern & LAURÉN(Type) & BPAGastric Pattern & LAURÉN(Type) \\
\hline Tubulo-papilliferous & Intestinal & Tubulopapilliferous(foveolar)* & Intestinal \\
Tubular well differentiated & Intestinal & Microtubular* & Intestinal \\
Tubular mild differentiated & Intestinal & Mucinous mucocellular - Poorly differentiated & Diffuse \\
& & Mucinous muconodular - Poorly differentiated & Diffuse \\
\hline
\end{tabular}

* Some pathologists classify these tumors as Laurén's intestinal type.

Table 2 - Lengths of columnar epithelium and adenocarcinoma. Distances from adenocarcinoma to gastroesophageal junction: distances from the adenocarcinoma to the squamous-columnar transition after esophageal resection for treatment of adenocarcinoma in Barrett's esophagus.

\begin{tabular}{lllll}
\hline Patient & Barrett's esophagus length $(\mathrm{cm})$ Tumor length $(\mathrm{cm})$ & Dist. Tu-GEJ $(\mathrm{cm})$ & Dist. Tu-Tepit. $(\mathrm{cm})$ \\
\hline 1 & 16 & 3.6 & 14 & 0.4 \\
2 & 10 & 8 & 0.5 & 1.5 \\
3 & 4 & 3.0 & 1 & 0 \\
4 & 7 & 6.5 & 0 & 0.5 \\
5 & 8 & 5 & 0 & 3 \\
6 & 6 & 7.4 & 2.2 & 0 \\
7 & 3.5 & 3 & 0 & 0.5 \\
8 & 5 & 4.5 & 0.3 & 0.5 \\
9 & 10.7 & 2.2 & 5.5 & 2.5 \\
10 & 8 & 7 & 0 & 1 \\
11 & 6.5 & 1.5 & 1.5 & 3.5 \\
12 & 9.5 & 7 & 2.5 & 0 \\
13 & 6 & 2.5 & 0 & 3.5 \\
\hline Mean (SD) & $7.71(3.33)$ & $4.67(2.28)$ & 2.07 & 1.30 \\
\hline Min & 3.5 & 1.5 & 0 & 0 \\
\hline Max & 16 & 7.4 & 14 & 3.5 \\
\hline
\end{tabular}

Dist. Tu-GEJ = Distance from distal limit of the tumor to the gastroesophageal junction. Dist. Tu-Tepit = Distance from the proximal limit of the tumor to the epithelium (columnar-squamous) transition. 


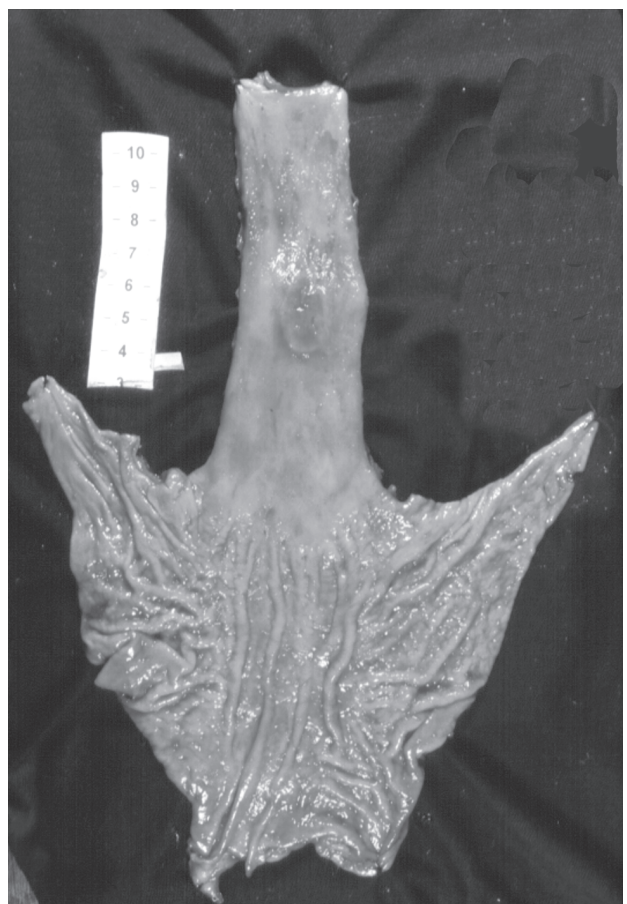

Figure 1 - Undifferentiated adenocarcinoma in Barrett's esophagus with $10.7 \mathrm{~cm}, 5.5 \mathrm{~cm}$ distant from gastroesophageal junction.

mal limit of the tumors and the columnar-squamous transition (Dist. Tu-Tepit) ranged from tumors reaching the epithelium transition (Tepit) to some $3.5 \mathrm{~cm}$ away from Tepit (mean $1.30 \mathrm{~cm}$ ). Eight tumors $(61.5 \%)$ were located less than $1.0 \mathrm{~cm}$ from Tepit.

Histopathological classifications of adenocarcinomas and their adjacent columnar epithelia are presented in Table 3. Two patients $(15.4 \%)$ did not have intestinal metaplasia in epithelium adjacent to the adenocarcinoma but rather had gastric columnar epithelium (Figure 2). Two patients $(15.4 \%)$ had only intestinal metaplasia epithelium

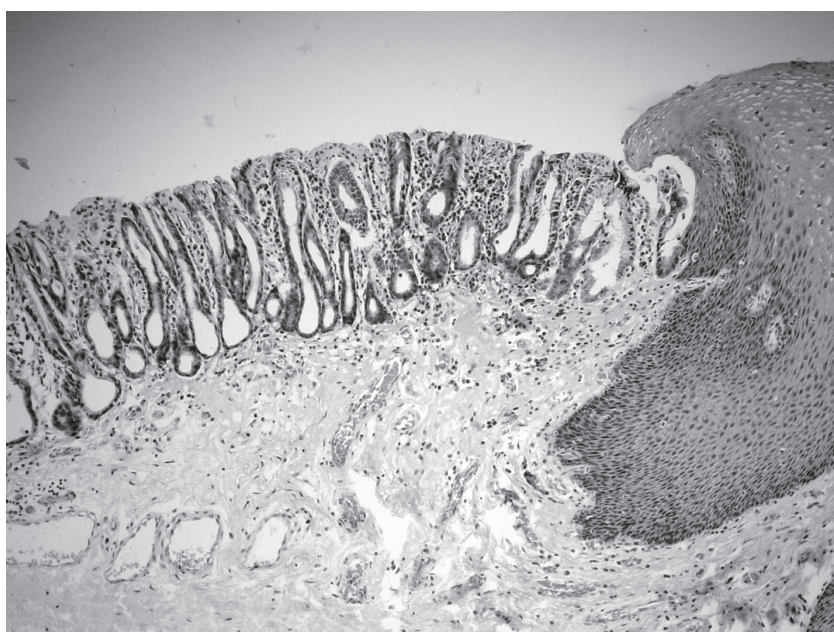

Figure 2 - Columnar epithelium in distal esophagus without intestinal metaplasia (Barrett's esophagus of gastric type).

beside the tumor; and 9 (69.2\%) had both intestinal metaplasia and gastric epithelium adjacent to the adenocarcinoma (one predominately intestinal and 8 predominantly the gastric type).

According to the Laurén's classification, 8 patients (61\%) presented with intestinal and $5(39 \%)$ with diffuse type tumors. Following the BPA classification, 10 patients presented with adenocarcinoma of the gastric pattern (77\%) and $3(23 \%)$ of the intestinal pattern. Three $(23 \%)$ of the gastric pattern tumors were tubulo-papilliferous (foveolar structure) (Figure 3), 2 (15\%) were microtubular, and 5 (39\%) were poorly differentiated. One of the intestinal pattern was well differentiated (8\%), and 2 were mildly differentiated $(15 \%)$. The gastric pattern tumors classified as microtubular and tubulo-papilliferous with foveolar structure, following the BPA classification, were defined as intestinal pattern when analyzed by Laurén’s classification (Figure 4).

Table 3 - Histological study: adjacent columnar epithelium and adenocarcinoma in Barrett's esophagus - Brazilian Pathology Association's (BPA) and Laurén's classifications.

\begin{tabular}{|c|c|c|c|c|}
\hline Patients & $\begin{array}{l}\text { Columnar epithelium } \\
\text { Type }\end{array}$ & $\begin{array}{l}\text { Adenocarcinoma } \\
\text { BPA }\end{array}$ & & LAURÉN \\
\hline 1 & Mixed & Tubular, well differentiated & Intestinal & Intestinal \\
\hline 2 & Intestinal & Tubular, mildly differentiated & Intestinal & Intestinal \\
\hline 3 & Mixed & Tubulo-papilliferous. (foveolar structure) & Gastric & Intestinal \\
\hline 4 & Intestinal & Tubular, mildly differentiated & Intestinal & Intestinal \\
\hline 5 & Mixed & Poorly differentiated & Gastric & Diffuse \\
\hline 6 & Gastric & Tubular (foveolar structure) & Gastric & Intestinal \\
\hline 7 & Gastric & Microtubular & Gastric & Intestinal \\
\hline 8 & Mixed & Poorly differentiated & Gastric & Diffuse \\
\hline 9 & Mixed & Poorly differentiated & Gastric & Diffuse \\
\hline 10 & Mixed & Microtubular & Gastric & Intestinal \\
\hline 11 & Mixed & Tubulo-papilliferous. (foveolar structure) & Gastric & Intestinal \\
\hline 12 & Mixed & Poorly differentiated & Gastric & Diffuse \\
\hline 13 & Mixed & Poorly differentiated & Gastric & Diffuse \\
\hline
\end{tabular}

Mixed = columnar epithelium with intestinal metaplasia and gastric metaplasia . 
However, when the adjacent epithelium of these patients was studied, no intestinal metaplasia epithelium was seen in 2 of them.

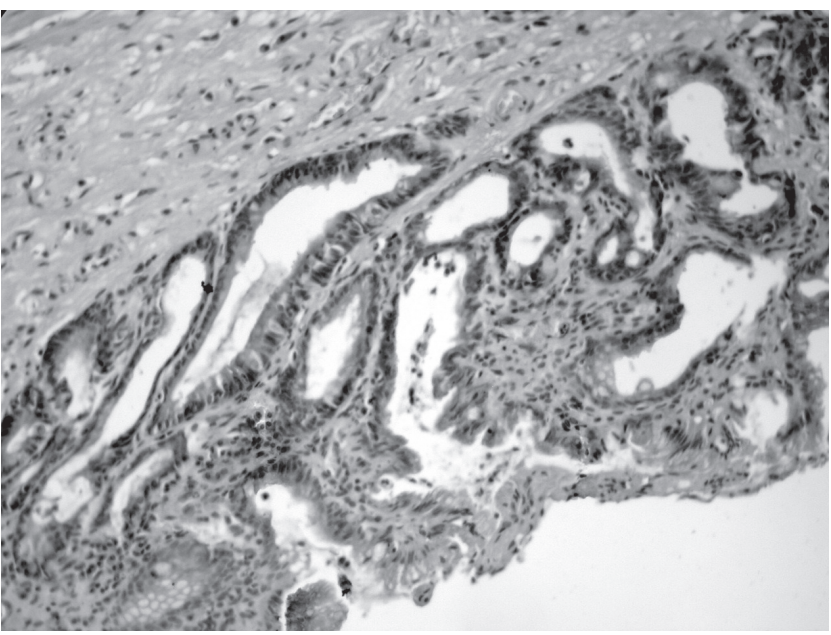

Figure 3 - Tubular adenocarcinoma with foveolar structure (originated in gastric cells)

\section{Immunohistochemical results}

The results of the immunohistochemical (IHC) analysis are listed in Table 4. The tests for Ki67 were moderately or strongly positive in all 13 patients for both the columnar epithelia and the adenocarcinomas.

Regarding the IHC reaction for p53 in the columnar epithelium adjacent to the tumor, we tested tissue from 9 patients. The IHC reaction to p53 was absent in 6 patients $(66.7 \%)$, minimal in $1(11.1 \%)$, mild in $1(11.1 \%)$, and maximal in another $1(11.1 \%)$. Regarding the IHC reaction for p53 in the adenocarcinoma, we tested tissue from 12 patients. Reactions to p53 were absent in 5 patients $(41.7 \%)$,
BPA Histophatologic classification

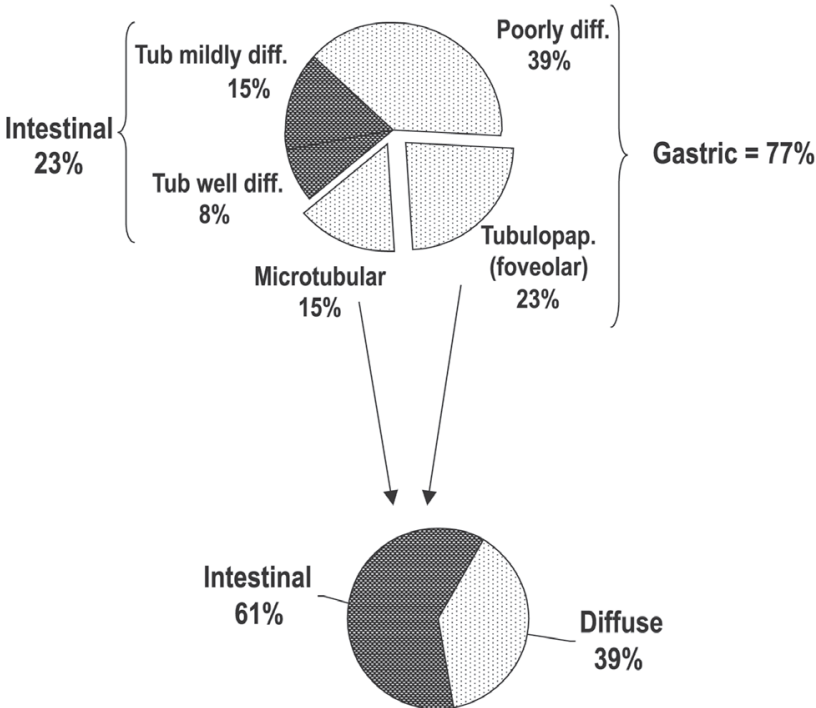

Laurén's Classification

Figure 4 - Difference between Laurén's and Brazilian Pathology Association's (BPA) classifications, with migration of tumors from the gastric (BPA) to the intestinal (Laurén) classification. Tub = tubular; $\operatorname{diff}=$ differentiated; tubulopap $=$ tubulo-papilliferous

minimal in $1(8.3 \%)$, and maximal in $6(50 \%)$. Three patients expressed p53 in the tumor but not in the adjacent columnar epithelium. Three patients expressed p53 in both tumor and columnar epithelium.

There was no clear relationship between the IHC reaction for p53 in columnar epithelia and adjacent adenocarcinomas for any combination of tissue types (Tables 3 and 4). In 3 patients with mixed columnar epithelium having gastric or intestinal metaplasia, reaction to p53 in the epi-

Table 4 - Immunohistochemical (IHC) study results: analysis of Ki67 and p53 expression in columnar epithelium and adenocarcinoma.

\begin{tabular}{lcccc}
\hline Patients & Ki67BE & Ki67Adenocarcinoma & p53BE & p53Adenocarcinoma \\
\hline 1 & + & +++ & - & ++ \\
2 & $*$ & ++ & $*$ & - \\
3 & $*$ & +++ & $*$ & $*$ \\
4 & $*$ & $*$ & ++ & +++ \\
5 & ++ & ++ & + & ++ \\
6 & $*$ & ++ & - & ++ \\
7 & + & +++ & - & - \\
8 & ++ & +++ & - \\
9 & +++ & - & - \\
11 & ++ & ++ & \\
12 & ++ & +++ & + \\
13 & +++ & +++ & - & + \\
\end{tabular}

* Paraffin material not available. (-) No IHC reaction; (+) Minimal IHC reaction; (++) Moderate IHC reaction; (+++) Maximal IHC reaction; $\mathrm{BE}=$ Barrett's esophagus 
thelium was negative but was positive in the adjacent tumor. Conversely, 2 patients that had positive p53 tests in their tumors also had positive p53 tests in the adjacent columnar epithelium. In the 2 patients with gastric type columnar epithelium, tests for p53 in their tumors were positive, but in the columnar epithelium, 1 tested positive and 1 negative for p53. Four patients having diffuse or intestinal type tumors and mixed columnar epithelium had negative tests for p53 for both tumor and epithelial tissue.

One patient who presented with mixed columnar epithelium with gastric and intestinal metaplasia had p53 expressed just in gastric cells and never in goblet cells. In this patient, the tumor was classified as a gastric pattern by BPA (poorly differentiated) and diffuse by Laurén's classification, with p53 expression in some areas of the tumor lamina. This kind of expression suggests that the adenocarcinoma developed from gastric type epithelium, without intestinal metaplasia.

\section{DISCUSSION}

Prevalence of $\mathrm{ABE}$ has been decreasing in the last 2 decades in our service, as well as in other services. ${ }^{44,45}$ In our hospital, the prevalence decreased from $16 \%$ in $1987^{45}$ to $5.7 \%$ in this study. This reduction might be explained by the higher number of endoscopic examinations presently performed in patients with fewer symptoms, thus increasing the diagnosis of Barrett's esophagus without adenocarcinoma ${ }^{46}$ and decreasing the prevalence rate.

Short Barrett's esophagus segments can be a risk factor for development of adenocarcinoma, but this is not well documented because many previous studies excluded patients with short Barrett's esophagus segments from followup. ${ }^{15,20}$ Some authors describe a lower prevalence of adenocarcinoma associated with short Barrett's esophagus segments, since the risk area for developing a malignancy (columnar epithelium) is smaller. ${ }^{3}$ In this study, however, an adenocarcinoma developed only in cases of long Barrett's esophagus segments (mean $7.71 \mathrm{~cm}$ ). This finding had previously been observed in our service, with a mean Barrett's esophagus segment length of $9.7 \mathrm{~cm}$ for patients developing adenocarcinoma. ${ }^{29}$

The location of ABE seems to correlate with the length of the columnar epithelium. Nearly one third of patients had the tumor distally next to the GEJ, and another one extended past it. In other patients, the tumor was up to $14 \mathrm{~cm}$ away from the GEJ, which correlates with lengthier columnar epithelia. Tumors tended to be located next to the squamous-columnar transition, and the mean distance to the latter was $1.3 \mathrm{~cm}$. The same was observed in 13 patients with precocious adenocarcinoma. These findings suggest that this area should be specifically targeted during $\mathrm{ABE}$ follow up, with endoscopic biopsies. ${ }^{26}$

Nakamura et al. performed detailed study of gastric mucosa microcarcinomas and described the histogenesis of adenocarcinoma. ${ }^{31}$ They examined stomach resections performed because of benign diseases and identified tumors less than $2 \mathrm{~mm}$ and between 2 and $5 \mathrm{~mm}$ in length. The results confirmed that mucocellular adenocarcinoma developed from the gastric mucosa itself, and tubular adenocarcinoma from atrophic mucosa with intestinal metaplasia. Next, when they studied tumors greater than $6 \mathrm{~mm}$, they found the same relationship of the tumor with the adjacent columnar epithelium. With statistical analysis they proved that gastric or undifferentiated adenocarcinomas were related to gastric mucosa (with pyloric or fundic glands), while the intestinal pattern or differentiated adenocarcinomas were related to the presence of intestinal metaplasia. ${ }^{31}$ This description of the histogenesis agrees with our findings, since by the BPA classification, the ABE pattern showed a direct relationship with the adjacent columnar type, independent of the presence of intestinal metaplasia.

Laurén's classification identified more intestinal adenocarcinomas $(61 \%)$ than the BPA classification $(23 \%)$. This occurred because there was a migration factor, with tumors classified as gastric pattern in the BPA classification (tubular or tubulo-papilliferous with foveolar structure and microtubular adenocarcinomas) migrating to intestinal types in Laurén's classification. In the latter, the histogenesis of tumors is not taken into consideration, but rather only their morphological aspects. The BPA classification, modified from Nakamura, considers both the histogenetic and the morphological aspects. Thus, adenocarcinomas are considered to develop from gastric glandular epithelia and present tubular structure and foveolar or microtubular morphology.

Most pathologists classify ABE according to morphological classifications; therefore, the microtubular and foveolar structure adenocarcinomas are more frequently classified as intestinal adenocarcinomas, and this explains their high incidence rates in the international literature..$^{9,10,23,26}$ However, undifferentiated or gastric (signet ring cells and mucocellular) adenocarcinomas have been described by some authors, with lower incidence..$^{9,21,23}$ These tumors can originate from gastric metaplasia that is also present in the specialized epithelium of Barrett's esophagus.

The cell proliferation index, as revealed by IHC tests for Ki67 and possible genetic mutations (p53 gene and others), have been extensively reported in the literature, with the aim of identifying the evolution of Barrett's esophagus to adenocarcinoma. ${ }^{41,43,44}$ The relationship of the adenocarcinoma with its adjacent columnar epithelium had not been studied. 
We observed extensive expression of Ki67 in our material, showing a high cell proliferation index, both in the tumors and in the columnar epithelia. Other authors have reported lower expression of Ki67 (14\%) in patients with Barrett's esophagus without adenocarcinoma, and higher (87\%) in patients with ABE. ${ }^{44}$ Halm et al. found higher expression of Ki67 in Barrett's esophagus with intestinal metaplasia compared with Barrett's esophagus with gastric metaplasia, and rates were even higher in ABE. ${ }^{41}$ We did not observe any differences between Ki67 expression in different columnar epithelial metaplasias. Probably, the extensive Ki67 expression in both tumors and columnar epithelium could be explained by the fact that both tissue types were removed from patients who had already developed ABE.

We found low p53 expression, just 33\% in adjacent epithelia, and $58 \%$ in adenocarcinomas. This could be a sign of normal protein accumulation in the cell nuclei, without confirmed genetic mutation. Other authors describe p53 expression ranging from $60.9 \%$ to $65 \%$ in invading carcinomas. ${ }^{46,48}$ The p53 gene function may be inactivated by other mechanisms without a direct relationship to genetic mutation. On the other hand, some mutations observed in molecular biology do not yield positive expression of p53 in IHC studies. ${ }^{27,49,50}$

Expression of p53 in adenocarcinoma and adjacent columnar epithelium was not correlated in our study. Three patients with positive tumor expression of p53 did not express this in the adjacent epithelium, and we did not observe any quantitative evolution in p53 expression when adjacent columnar epithelium and adenocarcinoma were compared.

Molecular events such as mutations, allelic loss, genomic instability, and genetic methylations do not occur systematically, which makes a standard molecular development of ABE difficult to find.

The p53 expression in one patient in our study (\# 12) suggests that the epithelial origin of the tumor was in a gastric cell without intestinal metaplasia; however, it is only one case, and further studies should be conducted to correlate the histogenesis of the tumors and genetic markers.

\section{CONCLUSION}

Currently, anatomopathological aspects are still the best biological indicators for Barrett's esophagus follow-up with the purpose of obtaining early diagnosis of ABE. The most important area to search for precocious adenocarcinoma during endoscopic examination is the transitional region between squamous and columnar epithelium. Segments of Barrett's esophagus longer than $3 \mathrm{~cm}$ should be a red flag for increased risk for development of adenocarcinoma and indicate the need for close follow-up.

Adenocarcinoma does not always develop over intestinal metaplasia epithelium (2 patients, $15.4 \%$, did not present with intestinal metaplasia). The presence of intestinal metaplasia does not mean that this epithelium will originate a tumor. According to Nakamura, an adenocarcinoma can develop from gastric cells (foveolars). Barrett's esophagus is a columnar epithelium that can be modified, just as the gastric mucosa can, and it can originate any type of adenocarcinoma.

We conclude that follow-up in cases of long Barrett's esophagus segments (more than $3 \mathrm{~cm}$ ) is important and should be performed in all patients, independent of the type of columnar epithelium, with or without intestinal metaplasia, as revealed by endoscopic biopsy.

\section{RESUMO}

SZACHNOWICZ S e col. Origem do adenocarcinoma no esôfago de Barrett: bases histopathológicas e expressão dos genes p53 e Ki67. CLINICS 60(2):103-112, 2004.

O esôfago de Barrett é definido como a substituição do epitélio escamoso do esôfago distal por epitélio colunar. A metaplasia intestinal no esôfago de Barrett é considerada por muitos como o principal fator de risco para o desenvol- vimento do adenocarcinoma. Embora já descrito, o adenocarcinoma do tipo difuso e o esôfago de Barrett sem metaplasia intestinal, são raros e pouco estudados.

OBJETIVO E MÉTODO: O presente estudo objetivou o cálculo da prevalência do adenocarcinoma no esôfago de Barrett, assim como a análise macroscópica e microscópica detalhada de treze pacientes operados no período de 1990 a 2002, com realização de estudo imunohistoquímico do 
p53 e Ki67, correlacionando o tipo de tumor com o epitélio adjacente a este.

RESULTADOS: Obtivemos uma prevalência de 5,7\% de adenocarcinoma em pacientes internados para tratamento cirúrgico de esôfago de Barrett . Encontraram-se tumores relativamente grandes, com média de 4,67 $\pm 2,28 \mathrm{~cm}$, e sempre em esôfago de Barrett longo, com média de 7,71 \pm 1,5 $\mathrm{cm}$. Observou-se tendência de os tumores se localizarem próximos à transição escamo-colunar. $\mathrm{O}$ estudo histológico mostrou dois pacientes $(15,4 \%)$ que apresentavam esôfago de Barrett adjacente ao tumor do tipo juncional sem presença de metaplasia intestinal. Classificaram-se os tumores segundo a classificação japonesa de Nakamura (23\% de padrão diferenciado ou intestinal e $77 \%$ de padrão indiferenciado ou gástico) e pela classificação de Laurén (61\% intestinais e 39\% difusos). A diferença decorre da migração dos tumores microtubulares e foveolares do padrão gástrico para o tipo intestinal de Laurén. O estudo do Ki67 foi fortemente positivo em todos os pacientes, mostrando o alto índice de proliferação celular no epitélio colunar e no tumor. O p53 mostrou-se negativo em 66,7\% dos pacientes no epitélio colunar e $41,7 \%$ no tumor, não mostrando correlação entre os dois materiais.

CONCLUSÃO: O adenocarcinoma se desenvolve sobre o esôfago de Barrett a partir do epitélio colunar misto, intestinal, bem como do juncional, apresentando padrão tanto gástrico como intestinal; portanto tumores podem se desenvolver em epitélio colunar sem metaplasia intestinal o qual também deve ser seguido, principalmente quando for extenso.

UNITERMOS: Esôfago de Barrett. Refluxo Gastroesofágico. Neoplasia de Esôfago. Adenocarcinoma. Imunohistoquímica.

\section{REFERENCES}

1. Appelman HD. Is the presence of specialized epithelium necessary for the diagnosis of Barrett's esophagus? In: Giuli R, Tytgat GNJ, Demeester TR, Galmiche JP, editors. O.E.S.O. - The esophageal mucosa. Amsterdam, Elsevier Science, 1994, p. 878-9.

2. Reid BJ. Barrett's esophagus and esophageal adenocarcinoma. Gastroenterol Clin North Am 1991;20:817-34

3. Schnell TG, Sontag SJ, Chejfec G. Adenocarcinomas arising in tongues or short segments of Barrett's esophagus. Dig Dis Sci 1992;37:137-43.

4. DeMeester SR, DeMeester TR. Columnar mucosa and intestinal metaplasia of the esophagus-fifty years of controversy. Ann Surg 2000;231:303-21.

5. Sampliner RE. Practice guidelines on the diagnosis, surveillance, and therapy of Barrett's esophagus. The Practice Parameters Committee of American College of Gastroenterology. Am J Gastroenterol 1998; 93: 1028-32.

6. WARING JP. Barrett's esophagus: current concepts in diagnosis and management. Conference Report. SAGES Annual Scientific Session and Postgraduate Course. March 29-April 1, 2000. In: Medscape Gastroenterology, 2000, v 2.

7. Saubier EC, Gouillat C, Samaniego C, Guillaud M, Moulinier B. Adenocarcinoma in columnar-lined Barrett esophagus. Analysis of 13 esophagectomies. Am J Surg 1985;150:365-9.
8. Paraf F, Fléjou JF, Potet F, Molas G, Féketé F. Esophageal squamous carcinoma in five patients with Barrett's esophagus. Am J Gastroenterol 1992;87:746-50.

9. Paraf F, Fléjou JF, Pignon JP, Fékété F, Potet F. Surgical pathology of adenocarcinoma arising in Barrett's esophagus. Analysis of 67 cases. Am J Surg Pathol 1995;19:183-91.

10. Spechler SJ, Zerooglan JM, Antonioli DA, Wang HH, Goyal RK. Prevalence of metaplasia at the gastro-esophageal junction. Lancet 1994;344:1533-6.

11. Morales, TG, Sampliner RE, Bhattacharya A. Intestinal metaplasia of the gastric cardia. Am J Gastroenterol 1997;92:414-8.

12. Spechler SJ, Goyal RK. The columnar-lined esophagus, intestinal metaplasia, and Norman Barrett. Gastroenterology 1996;110:614-21.

13. Frindlay L, Kelley AB. Congenital shortening of the esophagus and the thoracic stomach results therefrom. Proc R Soc Med $1931 ; 24: 1561-78$

14. Allison PR, Johnstone AS. The esophagus lined with gastric mucous membrane. Thorax 1953;8:87-101.

15. McClave SA, Boyce HW Jr, Gottfried MR. Early diagnosis of columnar-lined esophagus: a new endoscopic criterion Gastrointest Endosc 1987;33:413-6. 
16. Cameron AJ, Kamath PS, Carpenter HA. Prevalence of Barrett's esophagus and intestinal metaplasia at the esophagogastric junction. Gastroenterology (Abstract) 1997;A82:112.

17. Haggitt RC, Tryzelaar J, Ellis FH, Colcher H. Adenocarcinoma complicating columnar epithelium-lined esophagus. Am J Clin Pathol 1978;70:1-5.

18. Reid BJ, Rubin LE. When is the columnar lined esophagus premalignant? Gastroenterology 1985;88:A1552.

19. Reid BJ, Weinstein WM. Barrett's esophagus and adenocarcinoma. Annu Rev Med 1987;38:477-92.

20. Skinner DB, Walther BC, Riddell RH, Schmidt H, Iascone C, DeMeester TR. Barrett's esophagus: comparison of benign and malignant cases. Ann Surg 1983;198:554-65.

21. Ovaska J, Miettinen M, Kivilaakso E. Adenocarcinoma arising in Barrett's esophagus. Dig Dis Sci 1989;34:1336-9.

22. Tytgat GNJ, Hameeteman W The neoplastic potential of columnarlined (Barrett's) esophagus World J Surg 1992;16:308-12.

23. Peracchia A, Bonavina L. Barrett's esophagus: an up-to-date. Milan, Edra, 1999. 131p.

24. Potet F, Flejou JF, Gervaz H, Paraf F. Adenocarcinoma of the lower esophagus and the esophagogastric junction. Sem Diagn Pathol $1991 ; 8: 126$.

25. Cameron AJ, Lomboy CT, Pera M, Carpenter HA. Adenocarcinoma of the esophagogastric junction and Barrett's esophagus. Gastroenterology 1995; 103:1541.

26. Nishimaki T, Holsher AH, Schuler M, Bollsschweiler E, Becker K, Siewert JR, et al. Histopathologic characteristics of early adenocarcinoma in Barrett's esophagus. Cancer 1991;68:1731-

27. Ruol A, Parenti A, Merigliano S, Zaninotto G, Bonavina L, Galiotto, $\mathrm{M}$ et al. Intestinal metaplasia: is it the common precursor of both adenocarcinomas in Barrett's esophagus and of the gastric cardia. In: Peracchia A, Bonavina L editors. Barrett's esophagus: an up-to-date. Milan, Edra, 1999. v 1, p 49-61.

28. Jankowski JA, Wright NA, Meltzer SJ, Triadafilopoulos G, Geboes K, Casson AG. Molecular evolution of the metaplasia-dysplasiaadenocarcinoma sequence in the esophagus. Am J Pathol 1999; 154:965-73.

29. Cecconello I, Nasi A, Zilberstein B, Pinotti HW. What are the indications for resection in Barrett's esophagus? In: Giuli R, Tytgat GNJ, DeMeester TR, Galmiche JP, editors O.E.S.O. The esophageal mucosa. Amsterdam, Elsevier Science, 1994, p 9456.

30. Laurén P. The two histological mains types of gastric carcinoma: diffuse and so-called intestinal-type carcinoma. Acta Pathol Microbiol Scand 1965;64:31-6.

31. Nakamura K, Sugano H, Takagi K. Carcinoma of the stomach in the incipient phase: its histogenesis and histological appearances. Jpn J Cancer Res (gann) 1968;59:251-8.

32. Iriya K, Cury PM. Carcinoma do estômago. In: Bacchi CE, Almeida PC, Franco M 2nd, editors Manual de padronização de laudos histopatológicos - Sociedade Brasileira de Patologia. Rio de Janeiro, Reichmann \& Affonso Editora, 1999, p. 70-7.
33. Jones DR, Davidson AG, Summers CL. Potential application of p53 as an intermediate biomarker in Barrett's esophagus. Ann Thorac Surg 1994;57:598-603.

34. Johansson J, Johansson F, Walther B, Villen R. Adenocarcinoma in the distal esophagus with and without Barrett's esophagus. Br J Surg 1997;84:1470-3.

35. Bian YS, Osterheld MC, Bosman FT, Benhattar J, Fontolliet C. P53 gene mutation and protein accumulation during neoplastic progression in Barrett's esophagus. Mod Pathol 2001;14:397403

36. Safatle-Ribeiro AV, Ribeiro U, Sakai P, Clarke MR, Fylyk SN, Kim $\mathrm{R}$, et al. p53 is overexpressed in cancer and non-malignant tissues from patients with megaesophagus. Digestive Disease Week, 1996 [abstract].

37. Mandard AM, Marnai J, Lebeau C, Benard S, Mandard JC. Expression of p53 protein in oesophageal squamous epithelium from surgical specimens resected for squamous cell carcinoma of the oesophagus, with special reference to uninvolved mucosa. J Pathol 1997;181:153-7.

38. Flejou JF, Potet F, Muzeau F, Le Pelletier F, Fekete F, Henin D. Overexpression of p53 protein in Barrett's syndrome with malignant transformation. J Clin Pathol 1993;46:330-3.

39. Ireland AP, Clark GW, DE Meester TR. Barrett's esophagus. The significance of p53 in clinical practice. Ann Surg 1997;25:1730 .

40. SCHOLZEN T, GERDES J. The Ki67 protein: from the known and the unknown. J Cell Physiol 2000;182:311-22.

41. Halm U, Tannapfel A, Breitung B, Breidert M, Wittekind CW, Mossner J, et al. Apoptosis and cell proliferation in the metaplasiadysplasia-carcinoma-sequence of Barrett's esophagus. Hepatogastroenterology 2000;47: 962-6.

42. Banks L, Matlashewski G, Crawford L. Isolation of human-p53specific monoclonal antibodies and their use in the studies of human p53 expression.

Eur J Biochem. 1986;159(3):529-34

43. Krishnadath KK, Tilanus HW, Alers JC, Mulder AH, Van Dekken $\mathrm{H}$. Detection of genetic changes in Barrett's adenocarcinoma and Barrett's esophagus by DNA in situ hybridization and immunohistochemistry. Cytometry 1994;15:176-84.

44. Rioux-Leclercq N, Turlin B, Sutherland F, Heresbach N, Launois B, Campion JP, et al. Analysis of Ki-67, p53 and Bcl-2 expression in the dysplasia-carcinoma sequence of Barrett's esophagus. Oncol Rep 1999;6:877-82.

45. Pollara WM. Esôfago de Barrett: diagnóstico tratamento e seguimento tardio. São Paulo 1987. [Tese de Doutorado Faculdade de Medicina da Universidade de São Paulo].

46. Cameron AJ. Barrett's esophagus and adenocarcinoma: from the family to the gene. Gastroenterology (Editorials) 1994;102:1421-2.

47. Hölscher A, Bollschweiler E, Schneider PM, Siewert J. Prognosis of early esophageal cancer. Comparison between adeno- and squamous cell carcinoma. Cancer 1995;76:178-86. 
48. Segal F. Estudo da carcinogênese do adenocarcinoma de esôfago: análise imunohistoquímica e molecular do gene p53 em pacientes com metaplasia intestinal da cárdia e com esôfago de Barrett. Porto Alegre, 2002. [Tese de Doutorado - Faculdade de Medicina da Universidade Federal do Rio Grande do Sul].
49. Coggi G, Bosari S, Roncalli M, Graziani D, Bossi P, Viale G, et al. p53 protein accumulation and p53 gene mutation in esophageal carcinoma. A moleccular and immunohistochemical study with clinicopathologic correlations. Cancer 1997;7:425-32.

50. Hall PA, Lane DP. p53 in tumour pathology: can we trust immunohistochemistry? —Revisited! J Pathol 1994;172:1-4. 